\title{
Problems of Ensuring Ecological and Economic Security by Industrial Enterprises Under the Arctic Zone Conditions
}

\author{
Valeriia I. Pilipenko \\ Associate Professor, \\ Saint-Petersburg State University of \\ Economics, \\ Saint-Petersburg, Russia \\ alinapilipenko@mail.ru
}

\author{
Marina S.Vlasova \\ Associate Professor, \\ Saint-Petersburg State University of \\ Economics, \\ Saint-Petersburg, Russia, \\ vms68@yandex.ru
}

\author{
Tatyana B. Algina \\ Associate Professor, \\ Saint-Petersburg State University of \\ Economics, \\ Saint-Petersburg, Russia, \\ tatyanaalgina@yandex.ru
}

\begin{abstract}
Ensuring regional environmental and economic security is one of the priorities of the state. The problems of sustainable development of regions and their industrial complexes are considered by many scientists, however, insufficient attention is paid to the analysis of the sustainability of industrial enterprises in the Arctic zone (AZ) and their impact on the ecological and economic security of the region. Many of the problems of theoretical and methodological support for improving this security remain underestimated. For industrial enterprises of the Far North as a part of AZ, it is necessary to use a special approach to the development of methodological aspects of ensuring environmental and economic security due to the significant role that entrepreneurial activity has in the socio-economic development of the region and in the environmental situation.
\end{abstract}

The purpose of the research is the formation of a mechanism to ensure the environmental and economic security of the Russian Arctic zone (RAZ), as a region where industrial enterprises operate. The object of the research was the ecological and economic security of the region of the Arctic zone, which exists in the modern conditions of globalization of the economy and the increasing influence of geopolitical factors. The subject of the study was a set of problems of a theoretical, methodical and applied nature, related to the development and implementation of a model for the development of industrial enterprises in the Arctic zone. The factors limiting the development of industrial enterprises of the Far North are formulated. A system of indicators for the sustainable development of industrial enterprises and the environmental and economic security of the region of the Arctic zone of Russia is proposed. The interrelation of indicators of the development of industrial enterprises of the Arctic zone with the conditions of the external economic environment has been revealed, which made it possible to conclude that the structure of industrial production in the regions of the Russian Arctic is distorted. This, in turn, necessitates the formation of maritime clusters and the development of small and medium-sized businesses in the industrial sector. A comparative description of the key areas of state regulation of industrial enterprises in foreign and domestic practice has been carried out. The recommendations of the possible use (adaptation) of international experience in the Russian Arctic are formulated.

Keywords-ecological and economic security, sustainable development, Arctic zone, maritime clusters.

\section{INTRODUCTION}

The Russian Arctic zone plays an important role in ensuring the dynamic development of the country; more than $25 \%$ of the gross domestic product (GDP) is produced there. The industrial sector of the northern regions of Russia forms more than $40 \%$ of the gross value added in industry (in Russia this indicator is 31\%) [1]. The dominance of industrial production in the northern regions will continue, which is largely determined by a significant resource base. This in turn affects the prospects for industrial development throughout Russia. At the same time, the main task is to shift the priorities of the export orientation of non-renewable resources towards solving the issues of their processing by Russian companies, including those in the Arctic zone. A rather difficult economic situation necessitates the development of tools for making strategic and operational risk management decisions in crisis situations and overcoming their consequences.

In these circumstances, there is a likelihood of negative trends in the socio-economic development of individual territories. Along with the internal causes of the crisis, it is also necessary to take into account the influence of exogenous factors of external forces represented by the indicators of the world and national economies, as well as the regional policy pursued. The task of studying the influence of external factors with the aim of identifying the signs and causes of deviations in the development of industrial enterprises in the Far North is becoming highly relevant today [2]. All of these require a special approach to the development of methodological aspects of environmental and economic security. Tools and methods for ensuring the environmental and economic security of the Arctic region of Russia are considered by the authors from the position of a systematic approach as constituent elements of the sustainable development of the territory. The impact of adverse socio-economic factors on business development increases the importance of developing programs to adapt them to the influence of the external environment. For the latter, the characteristic properties

Print ISSN 1691-5402

Online ISSN 2256-070X

http://dx.doi.org/10.17770/etr2019vol1.4089

(C) 2019 Valeriia I. Pilipenko, Marina S.Vlasova, Tatyana B. Algina. Published by Rezekne Academy of Technologies.

This is an open access article under the Creative Commons Attribution 4.0 International License. 
are mobility, uncertainty and instability. Support for business activities, especially in the conditions of the Extreme North, is aimed at creating conditions for the economic growth of these territories: the more stable the system being created, the higher the level of security.

At the same time, the current state of intensive development of AZ implies the need to assess the planned parameters of the effectiveness of the development of the Arctic. One cannot but agree that, for AZ, the effectiveness of the activities of economic actors should not be considered traditionally only from the standpoint of estimating volumes and quantities [3].

\section{MATERIALS AND METHODS}

In May 2017, the strategy of Russia's economic security for the period up to 2030 was approved [4]. The decree establishes the fundamental indicators of economic security. From the point of view of the authors, the definition of indicators characterizing the change in the state of $A Z$ in a strategic perspective should be carried out from the standpoint of environmental safety of the region for the population living there, for the animal and plant world, for the water, underground and air environment belonging to the Earth. Therefore, it is advisable to consistently disclose the authors' approaches concerning the selection of indicators of assessment and environmental safety for $\mathrm{AZ}$ and definitions of modern forms of interaction between economic actors.

In the annual state report "On the state and environmental protection in the Russian Federation", a special section is devoted to issues of the RAZ, which contains information about a set of measures for nature conservation [5]. The state report also provides an assessment of the costs for enterprises in the protection of the environment. The largest amount of investment in the protection and rational use of natural resources in 2017 was noted in the Yamalo-Nenets autonomous district (67\%) and the Krasnoyarsk territory (21\%). Current expenses for environmental protection of RAZ in 2017 amounted to 32.13 billion rubles, and the largest amount was spent on waste management (44\%) and on the collection and treatment of wastewater (31\%).

The activities of industrial companies, oil-production and other forms of mining, as well as the operation of marine transport - all these together lead to the fact that there are areas in the Arctic with anthropogenically modified landscapes. Those landscapes need measures not only to conserve, but also to restore their natural ecological potential. The results of the work done in this context in 2017 are also presented in the Report. For example, Rosneft Oil Company, Gazprom, PAO Novotek and Lukoil approved of corporate programs for the conservation of biological diversity, taking into account the list of flora and fauna that determine the sustainable state of marine ecosystems of the Arctic. These companies conduct monitoring studies of animals, birds, listed in the Red Book of the Russian Federation and other natural objects on a regular basis.

In Murmansk region, Republic of Sakha (Yakutia) and in Khanty-Mansiysk autonomous region in 2017 various measures were taken to eliminate the accumulated environmental damage (reclamation of oil-contaminated land and sludge pits). Oil and gas companies have eliminated 184 accumulated sources of pollution.

An inventory of waste disposal sites is being carried out and in Murmansk region commissioning of the waste sorting line of the first eco-technology park in the Arctic zone of Russia as part of the waste sorting complex and solid municipal waste landfill took place.

The analysis of the activities carried out in the AZ for the purposes of maintaining and developing environmental safety according to the Report allows to draw conclusions that for the most part the activities are aimed at eliminating the results of pollution of water or land objects, rather than for anticipating possible negative effects for the ecological balance of the region. In addition, we would like to note that the question "Are these activities carried out by Russia sufficiently effective for the state of the environment?" has no clear answer in the Report.

For the region's environmental safety requirements to be met not after the identified damage, but to become a systemic activity of a proactive nature, it is necessary to approve the standard environmental safety indicators for enterprises which should be regularly monitored and implemented. It is advisable to choose the indicators that are defined as targets for the implementation of the "Environment Protection" state program [6], and supplement them with the new ones (indicated in italics in the text), namely:

- emission of air pollutants from stationary sources per 1 million rubles of gross domestic product at constant prices (in tons);

- the number of cities and urban settlements with high and very high levels of air pollution;

- the number of people living in adverse environmental conditions (in cities and urban-type settlements with high and very high levels of air pollution (air pollution index is more than 7 thousand people);

- volume of generated waste of all hazard classes per 1 million rubles of the gross domestic product at constant prices (in tons);

- the share of mammals listed in the Red Book of the Russian Federation and living in specially protected natural areas of federal significance in the total number of mammals listed in the Red Book of the Russian Federation (\%);

- the share of bird species listed in the Red Book of the Russian Federation and inhabiting specially protected natural areas of federal significance in the total number of bird species listed in the Red Book of the Russian Federation (\%);

- the percentage of the territory occupied by specially protected natural territories of regional and local importance $(\%)$; 
- the population living in the areas with unfavorable environmental situation, subject to the negative impact associated with the past economic and other activities (the number of people).

For the assessment of the environmental safety the acceptable thresholds which for the period up to 2025 can be set on the basis of the planned results of the state program:

- emissions of harmful (polluting) substances from stationary sources per a unit of gross domestic product should be reduced by 1.3 times;

- the number of cities and urban settlements with high and very high levels of air pollution should be reduced to 45 ;

- improving the environmental conditions for 36.4 million Russians currently living in the cities and urbantype settlements with a high and very high levels of air pollution;

- the volume of waste of all hazard classes per a unit of the gross domestic product should be reduced by 1.2 times;

- improving the environmental conditions of life for more than 700 thousand Russians living in the areas with unfavorable environmental situation associated with the past economic and other activities;

- preserving and increasing the population of the animal and plant world which are listed in the Red Book;

- application of an increase in the depreciation coefficient of 3 when calculating the tax on the profit of organizations making capital investments in the creation of objects of environmental protection;

- adjustment of the payment for the negative impact on the environment due to costs on the implementation of environment protection measures;

- providing loan financing for the implementation of environmental projects by the state development institutions.

For the economic security it is not the economic indicators themselves that matter, but their threshold values do. The criterion of economic and environmental safety can be called the requirement of finding the actual values of indicators within certain limits. Going beyond those limits will mean reducing the system security to an unacceptable level [7].

For the areas of the AZ in view of the objective development problems, among which one can single out poor transport accessibility, difficult climatic conditions, population ageing, it is also necessary to adjust generally accepted indicators of the economic security. In the course of the study a grouping of indicators of economic security was conducted for municipalities of the Far North. Indicators of the first group covered: natural population growth; the ratio of average per capita income to the subsistence minimum; investments in the fixed capital the volume of shipped goods of the own production; the share of manufacturing in the industrial production, in $\%)$.

Among the indicators of intensive use of the resource potential we highlight the following: the degree of deterioration of the fixed funds, in $\%$; industrial production per capita, in thousand rubles; the share of imported goods in the industrial potential, in \%. Specialization of the northern region has to be described by the ratio of the increase in mineral reserves to the volume of their repayment in the subsoil, in \%; extraction of fuel and energy minerals per capita, in thousand rubles; the ratio of electricity generation to its consumption.

The indicator characterizing the degree of economic development of the municipality can be a balanced financial result of the volume of the shipped goods of the own production. The state of the economic security of the industrial enterprises of the Northern region depends on the factors of development and on the quality of management of these factors. Therefore, it seems obvious that the existence of an effective system of the state regulation of industrial development of RAZ, is the most important condition for achieving the economic security of the Arctic region as a whole.

\section{RESULTS AND DISCUSSION}

According to the survey of the financial and economic activities of Norilsk industrial region for the period from 2015 to 2017, the authors have developed critical indicators that can characterize the economic security of the municipal district of the Arctic zone. Table I presents the recommended indicators and achieved ones. The following industries are represented in Norilsk industrial region: mining, non-ferrous metallurgy, power engineering, gas industry, transport, communications, construction industry, trade, food industry, housing and utilities. Missing data in Table I are indicated as n/d (no data).

The given system of indicators and their comparison with recommended values allow us to identify areas in which there are certain problems that do not allow a certain level of economic security. For Norilsk this is a decline in the population and the ratio of average per capita income to the subsistence minimum.

Creating a system of advanced strategic management and, in particular, a system of operational monitoring of the state of the economic security of industrial enterprises and analyzing the impact of the external environment on it involves selecting basic and calculated indicators of the state of the social and economic environment of the regions, their synthesis and the development of synthesized indicators. Based on the analytical work, this system can determine the most vulnerable points and influence of the external environment on the development of the region. 
TABLE I. Recommended Indicators Of The Economic Security For A Municipal District Of The Arctic Zone

\begin{tabular}{|c|c|c|}
\hline Indicators & $\begin{array}{l}\text { Critical } \\
\text { values }\end{array}$ & Norilsk \\
\hline natural population growth & more than 1 & 2 \\
\hline $\begin{array}{l}\text { - the ratio of per capita income to the subsis- } \\
\text { tence minimum }\end{array}$ & $\begin{array}{ll}\text { more } \\
3,5\end{array}$ than & 3,1 \\
\hline $\begin{array}{l}\text { - investments in fixed assets, as a percentage } \\
\text { of the volume of the shipped goods of the } \\
\text { companies' own production }\end{array}$ & $15-25$ & 17,7 \\
\hline $\begin{array}{l}\text { - share of manufacturing in industrial produc- } \\
\text { tion, in \% }\end{array}$ & 25 & 74,3 \\
\hline $\begin{array}{l}\text { degree of depreciation of fixed assets in in- } \\
\text { dustry, in } \%\end{array}$ & less 40 & 48,3 \\
\hline - industrial output per capita in rubles & $\begin{array}{l}\text { more } \\
250000\end{array}$ & 292 \\
\hline $\begin{array}{l}\text { - share of imported goods in industrial poten- } \\
\text { tial, in \% }\end{array}$ & less 20 & $\mathrm{n} / \mathrm{d}$ \\
\hline $\begin{array}{l}\text { - the ratio of the increase in mineral reserves } \\
\text { to their repayment volumes in the subsoil, in } \\
\%\end{array}$ & $\begin{array}{l}125 \\
\text { growth) }\end{array}(25 \%$ & $\mathrm{n} / \mathrm{d}$ \\
\hline $\begin{array}{l}\text { - mining of fuel and energy minerals per cap- } \\
\text { ita, in rubles }\end{array}$ & more than & 30,5 \\
\hline -ratio of power generation to its consumption & & $\mathrm{n} / \mathrm{d}$ \\
\hline $\begin{array}{l}\text { - balanced financial result to the volume of } \\
\text { the shipped goods of the companies' own } \\
\text { production }\end{array}$ & more than 1 & $\mathrm{n} / \mathrm{d}$ \\
\hline
\end{tabular}

Analysis of the impact of the global and local factors on the external environment of a region is impossible without establishing interrelations between indicators of the external environment, as well as monitoring their impact (direct or indirect) on indicators of monitoring the economic security and sustainable development. Having a complete picture of the interrelationships of the indicators can help us to obtain a consistent assessment of environmental factors affecting sustainable development as a criterion for economic security.

The authors have built correlation dependencies to determine the system of interrelations between analized indicators. The indicators characterizing the development of industrial enterprises (among them: the turnover of enterprises, the level of investment, innovative activity, industrial production index, profitability of production etc.) were selected for certain regions of the Far North. Correlation analysis was carried out for 8 regions of the Arctic zone and 30 indicators. In assessing the strength of the connection between the main indicators characterizing the industrial development of the regions of the Extreme North about 300 coefficients were calculated, and only $33 \%$ of the coefficients characterizing strong and average communications (more than 0.6) were found. The conclusion is made about the deformation of the structure of the industrial production in these regions of the Russian Arctic. This clearly indicates the need for further development of small and medium-sized businesses engaged in industrial production in the region.

We believe that the participation of the state in the development of industry in the northern regions is necessary as a significant resource of the industrial sector in these regions, with the raw materials orientation of the Russian economy, is of particular importance in exporting and forming the revenue side of the budget. A critical analysis of the foreign experience of the state regulation of the northern territories showed that the use of foreign experience is possible not so much in terms of specific details of regulating the industrial development of the northern regions, as in the general idea of the policy under consideration [8]. That is why foreign experience is of great interest, because it makes possible to avoid repeating conceptual errors.

The industrial activity of the northern states is based on the primary development of resource-extracting and resource-processing industries, by analogy with the industrial development of the northern territories of Russia. Considering the foreign experience in regulating the development of the northern territories, it should be noted that the main features are:

- dominant participation of large corporations in the development of the northern economies;

- active participation of the state, reflected in the continuous evaluation and modernization of the "northern" legislation, which gives additional benefits to organizations and enterprises engaged in economic activities in hard-to-reach areas.

State subsidies occupy the main share in the expenditure part of the budgets of underdeveloped territories, their value reaches $75 \%$. Managing the development of such territories is centralized; the state efforts are directed at improving the even distribution of income from the use of the natural resources of the North. This is typical of Canada and Nordic countries [9]. The solution of this problem has special features for each of the countries, but the general measures to stabilize the economic situation of the northern territories are traced, which have been as follows:

1) special regional stabilization funds have been created;

2) measures are being taken to diversify the economy;

3) control of the areas rich in natural resources;

4) the application of special tax regimes.

In our opinion one of the most important reasons for low the efficiency of the regional industrial policy in the North is the insufficient attention of the state bodies to sectoral and spatial and other local aspects. Hence the need for a systematic study of the development and implementation of the regional industrial policy in the Arctic zone, including cluster policy on the formation of maritime clusters [10], [11].

The state support for the creation of clusters in AZ should be an absolutely unique process both in its content and forms of implementation. Currently, an updated state program called "Social and economic development of the Russian Federation AZ for the period up to 2025" has been approved [12]. The state program sets its goal as raising social and economic development of Russian Artic Zone. The state program sets subprograms for the supporting development zones for the accelerated socio-economic 
development of RAZ; for the development of the Northern Sea Route and the provision of shipping in the Arctic; for the creation of equipment and technology of oil and gas and engineering necessary for the development of mineral resources in RA. The state program highlights the "frame-cluster approach", which is based on the advanced development of the transport, power engineering and social framework of the territory and the concentration of resources in the prioritized supporting zones of development. All this indicates the need for forming a special cluster policy of the Arctic zone of Russia. In such a cluster policy for RAZ, the objectives of the functioning of the clusters will be linked the objectives of the state program. This will allow legislation to justify the financing of the activities of marine and coastal AZ clusters. The state program identifies "core development zones" that will create conditions for accelerated socio-economic development of the AZ, and achieving strategic interests and ensuring Russia's national security in the Arctic. It is the cluster formation in the modern conditions of the socio-economic development of the country that can become these supporting development zones. All this indicates a real possibility and demand for creating clusters, for which a clearly formulated cluster initiative is also needed. Such an initiative coming from potential or existing cluster members, associated with the search for potential partners, investors, buyers of cluster products, is of particular importance. It is an extremely significant initiative compared to the actions of the state bodies, since it comes from the goal-oriented and more relevant participants (having scrupulous knowledge of the subject). The weakness of the cluster initiatives is the lack of special knowledge of the owners of the needed resources - investors, government agencies and buyers. Russian researchers determine the typology of maritime clusters, distinguish among the diversity of this type of clusters such characteristics as the presence or absence of trans-boundary and trans-aquatorial clusters in them; whether they are connected with marine economic activities or not [13]. For Russia, the creation of marine clusters has not been achieved yet. For EU countries, the functioning of maritime clusters is a part of EU modern economy that generates income and contributes to the effective development of regions, countries and companies in the maritime cluster. The European network of maritime clusters, which unites 18 EU member states, is well known [14]. The European Network of Marine Clusters supports joint projects for the development of clusters, creation of unified legislation, operating standards and other issues. Studying the problems of the functioning of the maritime clusters of the European Union, the countries of the Baltic region, and also the Asia-Pacific region and the proposed ways to solve them will allow the future RAZ maritime clusters to minimize the potential difficulties of their creation and development.

\section{CONCLUSIONS}

For the effective functioning of sea clusters in the Arctic zone, new hybrid forms of cluster formations, namely project alliances, can be used. The reasons for their emergence and implementation are the following objective factors: the feasibility of using the project approach is due to the global trend of reducing the life cycle of technologies and the need to use common crossborder operating standards, legislation, international agreements leads to the emergence of an alliance integration form. Since at present Russia is a party of about 100 international agreements in the field of environmental protection for the effective implementation of international requirements for environment protection and internal environment safety, the creation of marine clusters in Arctic Zone will allow a rational solution for these issues.

Regarding the authors' approach to increasing the attractiveness of the region for high-quality residence and tourism, it should be noted that AZ is a territory where people live permanently. Clusters have always contributed to increasing the employment of the region's population and to a significant increase in their satisfaction with salaries, living conditions, and other social criteria that characterize the quality of life of the population of AZ [15].

Creating a real-life cluster policy for the Arctic region of the Russian Federation, the further creation of marine clusters uniting large, medium and small enterprises, their use of approved indicators of environmental and economic security will allow in the foreseeable future a significant change in the attitude of people to the issue whether to live and work in the Arctic.

To develop the industry in AZ without the support of the state is impossible. Implementation of supportive measures should be based on the administrative, legal and economic opportunities of the state. First of all, it is necessary to correct the essential disproportions in the regional economy with the preferential use of centralized administrative levers. At the same time, the goals of the state policy should, in particular, include: promoting the development of priority industries, improving the quality of life of the population, ensuring the necessary volume of import under the state control over the export of strategic goods. In the future, the transition from the state administrative-restrictive measures to economic levers stimulating the development of the market structure and increasing the number of independent market managing entities will be carried out, which will lead to changing the structure of industry with a focus on competitive relationships.

These measures will contribute to the formation of a sustainable mechanism for ensuring the environmental and economic security of the industrial enterprises in the Russian Arctic. 


\section{REFERENCES}

[1] The Russian Federation Federal State Statistics Service Website [Online]. Available: http://www.gks.ru/free_doc/new_site/besopasn/ pok-besopasn.htm. [Accessed: Feb, 4, 2019] (in Russian)

[2] Chernogorskiy S., Shvetsov K., Parkhomenko V. Two Prediction Models for Some Economic Indicators of the Russian Arctic Zone. [Online]. Available: https://link.springer.com/chapter/10.1007/978-3-319-56994-9 25 [Accessed: Jan, 18, 2019]

[3] Agarkov S.A., Kozlov A.V., Fedoseev S.V., Teslya A.B. Major Trends in Efficiency Upgrading of the Economic Activity in the Arctic Zone of Russian Federation. In: Zapiski Gornogo institute. 2018. Vol. 230. P. 209-216. DOI: 10.25515/PMI.2018.2.209

[4] Decree of the President of the Russian Federation of May 13, 2017 No. 208 "On the Strategy of Economic Security of the Russian Federation for the Period up to 2030"[Online]. Available: http:// government.ru/docs/all/111512/ [Accessed: Jan, 10, 2019] (in Russian)

[5] State report "On the state and environmental protection of the Russian Federation in 2017'. [Online]. Available: http://www. mnr.gov.ru/docs/ /gosudarstvennyy_doklad_o_sostoyanii_i_ob_ okhrane_okruzhayushchey_sredy_rossiyskoy_federatsii_v_2017/ [Accessed: Jan, 15, 2019] (in Russian)

[6] State program "Environmental Protection" for 2012-2020. Approved by the Government Decree of April 15, 2014 No. 326. [Online]. Available: http://government.ru/programs/205/events/ [Accessed: Dec, 20, 2018] (in Russian)

[7] Denezhkina, I.E. The system of indicators for monitoring the economic security of the region / I. E. Denezhkina, D. A. Suzdaleva // Effective crisis management. - 2011. - № 3. - p. 96-101 [Online]. Available: https://doi.org/10.17747/2078-8886-2011-3-96-101 [Accessed: Oct, 15, 2018] (in Russian)

[8] Detter G.F. The genesis of national and regional innovation systems of the Arctic states in the context of their national innovation policies. Scientific Herald of the Yamalo-Nenets Autonomous District. 2015. T.88. № 3. C.15-33 [Online]. Available: https https:// elibrary.ru/item.asp?id=25811435 Available: https://papers.ssrn. com/sol3/papers.cfm?abstract id=2621775 [Accessed: Dec, 24, 2018] (in Russian)
[9] Economic Freedom of the World: 2013 Annual Report: [Online]. Available: http://www.cato.org/pubs/efw/ [Accessed: Jan, 15, 2019]

[10] Hasanat W. Searching for Synergies in International Governance Systems Developed in the Circumpolar North. McGill International Journal of Sustainable Development Law \& Policy. 2013. Vol. 9. N 2, p. 5-41. [Online]. Available: https://papers.ssrn.com/sol3/ papers.cfm?abstract_id=2621775[Accessed: Dec, 21, 2018]

[11] Heininen Lassi Finland's Arctic Strategy. [Online]. Available: http://www.geopoliticsnorth.org/index.php? option=com_content\&view=article\&id=151:june-2010-finland-recently-presented-its-first-arctic-strategy-\&catid=38:finland\&Itemid=106 [Accessed: Dec, 22, 2018]

[12] State program "Social and economic development of the Arctic zone of the Russian Federation". Approved by the Government Decree of April 21, 2014 No. 366. [Online]. Available: http://government. ru/programs/236/events/ [Accessed: Jan, 15, 2019] (in Russian)

[13] Druzhinin A.G., Gorochnaya V.V., Dets I.A., Lachininskii S.S., Mikhailov A.S. Transboundary Clusters in the Littoral Ar $\neg$ eas: Factors and Distinctive Features.Vestnik VolGU. Seriya 11: Estestvennye nauki. 2015. N 3, p. 68-79. DOI: http://dx.doi. org/10.15688/jvolsu11.2015.3.7 (in Russian).

[14] The 2018 annual economic report on the EU Blue Economy. [Online]. Available: https://enmc.eu/news/the-2018-annual-economic-report-on-the-eu-blue-economy/ [Accessed: Jan, 24, 2019]

[15] Maritime cluster analysis on the Central Baltic region. SmartComp Research Report No 1, December 2012 [Online]. Available:: $\quad$ http://www.ubc-sustainable.net/library/publication/ maritime-cluster-analysis-central-baltic-region-smartcomp-research-report-no-1 [Accessed: Dec, 23, 2018] 